\title{
2 We few, we happy few? Legal history in the GDR
}

\author{
Martin Otto
}

\section{Introduction: The very beginning}

By May 1945, Germany was totally defeated. Total reversal replaced total war. Universities had been closed during the last months of the war, and many of their buildings were destroyed or out of use. During wartime the number of students was already small, and with the peace and after political deliberation, legal lectures and teaching of legal history ceased to exist. But 1945 was not a 'Point of Zero': when the universities reopened in the following years, the National Socialist past was present. The official point of reference in all education was 'before 1933.' Yet courses in the 'History of Private Law' (Privatrechtsgeschichte) were not integrated into the official part of the legal studies until 1935 (Haferkamp, 2010), and taking up an older tradition of legal history seemed impossible. Some legal historians even considered abolishing the lines between German, Roman and Canonic legal history for a genuine new beginning. ${ }^{1}$ By the same token, the whole history of universities in the German Democratic Republic (GDR) had to face a vast number of contradictions.

On the one hand, the GDR defined itself as completely new-a renunciation of the evil German tradition, the first workers' and peasants' state. Only the 'good' parts of German heritage like Humanism, Enlightenment or 'progressive' culture were adopted. On the other hand, even the Communists knew that a total restart was impossible. Hence, a general tension between the remaining 'bourgeois' and the upcoming, new generation of Marxist scholars was accepted, and as long as the German reunification was the official aim of Soviet politics, ties between the universities in the East and the West were generally maintained and tolerated by the government. An idea of the common past with the Western neighbour and even a continuity in the 'good' parts of history were supported-as long as the leading role of the SED (Sozialistische Einheitspartei Deutschlands; Socialist Unity Party of Germany; "unity" refers to the merge of Communists and Social Democrats) was not disputed.

In legal sciences, there was at first sight less continuity. But as, for example, most non-socialist lawyers left the GDR by 1949, some traits that dated back to the pre-war years did exist. Most notable of them was the German civil code BGB (Bürgerliches Gesetzbuch) that was still in effect in both German states. In many 


\section{Martin Otto}

cases there was no real alternative in referring to the old scholars and tradition. German universities were mostly conservative, and the left-wing (not to speak of communist) scientists had composed a small minority already in the Weimar Republic. For the large part, academics were conservative and a considerable number of the university professors of the GDR had been in office already before 1945 .

Typical for German legal science since 19th century was the definition of jurisprudence as a historic discipline, resulting in a strong role of the legal historical studies as part of the university training. Likewise, the GDR could not offer legal studies without legal history, so legal historians were needed, and because there was no Marxist legal history before 1945, the continuity among legal historians was even bigger than in other legal disciplines. For the legal science of the GDR, the presence of the 'other' German state (and the jurisprudential research carried out within it) was self-evident, yet all the initiatives and research results from the 'West' were categorically rebuked. For the legal historiography of the GDR, the fact that it did not represent the stance of the 'whole German jurisprudence' was even more awkward since it did share a common national past-which often was the object of legal historical studies - with the 'Western' German legal historical writing. The research results derived from that common past and understanding of the essence of the common tradition were nevertheless in many places very different from the Western equivalent.

\section{Where have all the universities gone?}

During the first post-war years, the difference between 'Zones of Occupation' (Besatzungszonen) was small. Allied forces mostly kept politically quiet. Everywhere a lack of professors and scholarly literature was remarkable (Rückert, 1995). A genuine new beginning was intended, but in reality this was hopelessly impracticable, especially for the universities in the Soviet area of occupation.

Friedrich-Schiller-University Jena (originally founded in 1558) was reopened in October 1945 by the Soviet military government (Steiger, 1980). Like most parts of Thuringia, Jena was originally occupied by the US army. Under American rule, Thuringia seemed to be returning to the German 'rule of law' (Rechtsstaat) (Wahl, 1999). But American occupation lasted only one summer-and it had no effect on the university. Although Americans made plans to re-open Jena University, this only became reality under Soviet rule, and the university was faced with a marked 'brain drain' to West Germany, the Faculty of Law especially (Stolleis, 2009, pp. 100-109). When in October 1946, Hermann Schultze von Lasaulx finally left Jena, there were no remaining legal historians_-and it was not until 1949 that Gerhad Buchda returned from Halle to fill his place (Lingelbach, 2008).

Rostock University (originally founded 1419) was reopened in January 1946 (Lieberwirth, 1988, p. 195). The famous legal historian Heinrich Mitteis was a member of the Faculty of Law, but he left for Berlin in 1947, and legal history 
and church law were lectured by the enigmatic Hans Gotthilf Strasser (Mechow, 1970, p. 278 and Soldwisch, 2007, p. 225), a former journalist and member of the liberal political party LDPD (Liberal-Demokratische Partei Deutschlands). Strasser was also the Minister of Finance in Mecklenburg from 1946 to 1948 (Handschuck, 2003). The Rostock Faculty of Law was closed down for political reasons in 1951.

Leipzig University (originally founded 1409) was reopened in autumn 1945 (Lieberwirth, 1988, p. 194). Leipzig as well was first occupied by the Americans. The famous 'Jurist Faculty' (Juristenfakultät) began lecturing in January 1946. The Supreme German Court (Reichsgericht) was no longer in operation. The faculty of law boasted an impressive number of names from the old days, including Alfred Schultze in German legal history and Heinrich Siber in Roman legal history, both old-aged. Senior faculty member and long-term Dean was Erwin Jacobi, a former friend of Carl Schmitt and one of the leading public lawyers in the Weimar Republic with merits in labour law and church law. During the first post-war years, Leipzig was considered the most 'bourgeois' law faculty in the Soviet area of occupation (Stolleis, 2009, pp. 109-121).

In 1946 in Leipzig, the first post-war habilitation thesis in legal history (Lieberwirth, 1986) was passed by Gertrud Schubart-Fikentscher, a student of Alfred Schultze (Lieberwirth, 2010, pp. 1-26). The year 1947 saw the installation of the 'Social Science Faculty' or GEWIFA (Gesellschaftswissenschaftliche Fakultät, a Marxist faculty) and the 'Worker and Peasant Faculty' (Arbeiter-undBauern-Fakultät) in the 'socialist redesign' of the university. Another brain drain to West Germany began, concerning nearly all the lawyers with the exception of Jacobi (Otto, 2004), who in 1950 was the only non-socialist left. The teaching of legal history nearly disappeared completely, although this was not the intention of the politicians. When Jacobi died in 1965, the Leipzig faculty specialised in socialist economic law without covering legal history.

The traditional Prussian university, Martin-Luther-University Halle-Wittenberg (Wittenberg University was founded in 1502 Halle University in 1694), was reopened in February 1946 (Stolleis, 2009, pp. 93-99) with the returned POW Gerhard Buchda as the 'surviving' legal historian. Buchda, however, was soon dismissed for political reasons. The 78-year-old Rudolf Joerges, although specialised in economic law, went back to his scientific roots, and gave preliminary lectures in Roman law. In 1948, Gertrud Schubart-Fikentscher, now a member of the socialist SED, became the chair of legal history, the first female German professor of law (Lieberwirth, 2000). Schubart-Fikentscher made Halle into a hub of legal history in the GDR.

The world-famous Friedrich-Wilhelms University Berlin (founded 1809) reopened in January 1946. It was situated in the Soviet sector of Berlin, which eventually came completely under Communist rule (Will, 2010). After 1947, legal history was represented by Heinrich Mitteis, who left for Munich in the same year (Brun, 1991). Lectures by Gerhard Buchda, who soon left for Jena, were only given for a short time (Stolleis, 2009, p. 84). In 1949 the university was renamed Humboldt University. 
Ernst-Moritz-Arndt-Universität Greifswald (originally founded in 1456) was reopened in February 1946, though this coincided with the Faculty of Law closing down. The legal historians Bernhard Rehfeldt and Heinrich Molitor moved to West Germany. In 1958 small attempts to establish Marxist constitutional history were made by Karl-Heinz Schönherr in his position as 'Rubenow Chair for State Law, although these attempts ended with his sudden death in 1961 (Otto, 2009, p. 319).

\section{'Polak versus Mitteis'}

In the first years of the GDR the illusion that traditional approaches and Marxist science could coexist was still alive. Heinrich Mitteis and Karl Polak clearly revealed their differing views on legal history in the leading journal Neue Justiz (Mitteis, 1947 and Polak, 1947), but it was a debate that never was (Schröder, 2001). The orthodox Marxist Polak became the GDR's most influential lawyer and was a member of the official 'Council of State' (Staatsrat). With no chance of succeeding in the GDR, Mitteis decided to go to Munich University (Ogorek, 1994, pp. 34-36). Ironically, the consequence of this mock-debate was not the total withdrawal of 'bourgeois' legal history.

The GDR had no interest in losing all its non-socialist scientists, and in other fields, such as medicine, there was a real need for skilled professionals. From 1949 to 1957 , about 1.5 million people left the GDR, among them a large number of academics, and maintaining a proper academic sector caused an increasing need for manpower. Some parts of the GDR wooed non-communist scientists, even in the humanities. East German playwright Heiner Müller ironically called it a kind of socialist 'Popular Front Policy' (Volksfront) (Müller, 1992, p. 122):

[T] the cultural 'Popular Front' concept of the GDR belonged of course an alliance with the bourgeois, traditional and conservative university people. One was not allowed to criticise them. ${ }^{2}$

Müller's opinion was an extra-legal interjection, but especially fitting for legal history. Nevertheless the 'Popular Front Policy' had no effect on the continuing decline of legal history in the GDR. Even scholars sympathetic to the socialist state claimed that there was continuing discrimination and defamation of their field of study. Horst Schröder-who might have expressed his opinion as a disappointed Marxist-wrote: 'From the beginning until the end of the GDR, legal history was a politically defamed and theoretically discredited discipline.' (Schröder, 2001, p. 5). ${ }^{3}$

\section{Mostly no Marxists: Centres of legal history research in GDR}

Most legal historians were not Marxists. The GDR claimed to be the first German 'Worker and Peasant State,' but legal historians obviously did not care 


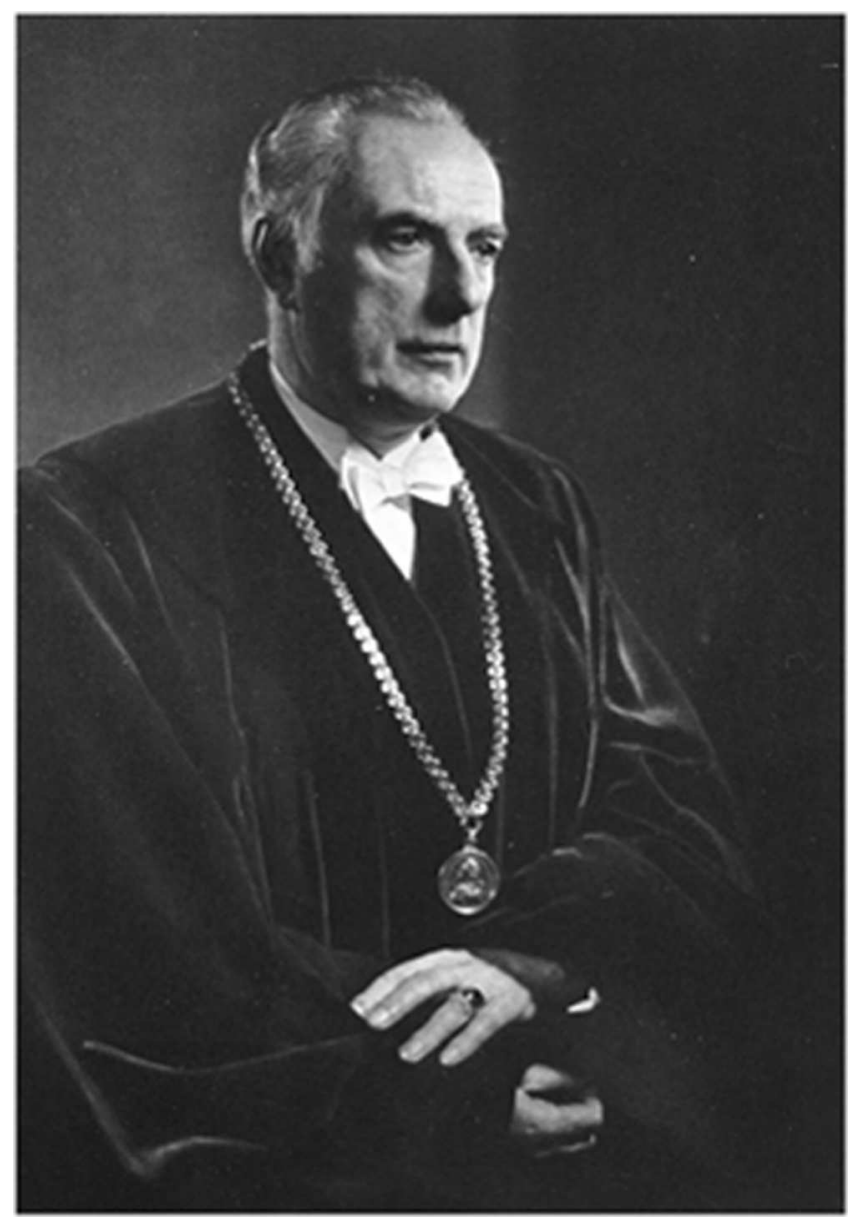

Figure 2.1 Heinrich Mitteis in 1937 as Dean of Vienna Legal Faculty. (Archiv der Universität Wien - Bildarchiv Signatur: 106.I.2986)

about this. In any case, they formed a minority among the comparatively small number of legal scientists, the 'happy few.' 4 They worked in a small niche and for political reasons they concentrated mostly on the German Middle Ages, the early modern age and the Enlightenment. Legal history was concerned with local issues, but it was also more conservative and traditional than in West Germany. Even the third GDR 'university reform' (Dritte Hochschulreform) in 1968 had in fact no effect on legal history. The 'old school' of GDR legal history consisted of two chairs pari passu. In 1951 the GDR government gave an order for university courses in legal history (Lieberwirth, 1988, pp. 196-197). They were initially intended to take place in each legal faculty in a to-be-founded 'Institute for Constitutional and Legal History' (Institut für 
Staats- und Rechtsgeschichte). In Leipzig such lessons were not arranged from above and the institute failed, more by chance than by intention. The neighbouring institute of Marxist legal philosophy in Berlin played a special role here, as will be discussed later. The most powerful places of traditional legal history in the GDR were at Jena and Halle.

\section{The Jena chair}

Jena chair was initially held by Gerhard Buchda (Lieberwirth, 1988, p. 198; see also the article of Adrian Schmidt-Recla and Zara Luisa Gries in this book). Born 1901 in Stadtroda (Sachsen-Altenburg, Thuringia), Buchda attended Jena University in 1923 and became a member of a conservative student fraternity. In 1929 Buchda wrote his thesis on the legal philosophy of natural law and Immanuel Kant under the supervision of the Romanist lawyer Hans Albert Fischer (Tilitzki, 2002, p. 179). In 1934 Buchda passed his habilitation in German private law and legal history on 'joint ownership' (Gesamthand) under the supervision of Rudolf Hübner und Arwed Blomeyer in Jena. After 1934 Buchda worked as a judge in Thuringia, where the NSDAP already played an important role in public service before Hitler came to power.

In 1937 Buchda joined the Sturmabteilung (SA) and accepted the chair of legal history at Prussian Halle in the following year (Lieberwirth 1996, pp. 30-31). He joined the NSDAP in 1939. His research interests covered traditional areas of German legal history (Hirtenschutt, i.e., 'shepherd's wages'), mostly history of procedural law, but also made innovative attempts in history of economic law (Buchda, 1938) according to Justus Wilhelm Hedemann. In 1943, Buchda joined the armed forces of Nazi Germany (Wehrmacht) but remained only a private during the war. Buchda lost his chair as did nearly all the former members of the NSDAP in the Soviet Occupation Zone; he was dismissed very early in 1945, but in 1949 he regained the chair of legal history and commercial law at Jena. In 1946 Buchda, a Lutheran, became a member of the liberal party LDPD, a political reservoir of the remaining 'bourgeois' on the way to a nearly no-ruling but legal 'Blockpartei' closely tied to the Socialist Unity Party of Germany or SED (Sozialistische Einheitspartei Deutschlands). Buchda focused on medieval and early modern legal history, especially 'juror chair' (Schöffenstubl) in Thuringia and Saxony. He made an edition of judgements from Pößneck court (Buchda, 1954-1962). Other publications concerned the German zoologist Alfred Edmund Brehm (Buchda, 1976). In 1958 Buchda became a member of the endangered Saxon Academy of Science in Leipzig and always kept in touch with colleagues in West Germany and abroad. From 1971 onwards he wrote many entries for the West German legal encyclopedia Handwörterbuch zur Deutschen Rechtsgeschichte. ${ }^{5}$ He served for a long time as the dean of the legal faculty, defending scientific standards against the gathering Marxism (Lenski, 2017, p. 112). He retired from the university in 1967. His role as a member of the NSDAP was never revealed (Waibel, 2011, p. 56); probably it wasn't even known. He died 1977 in his hometown of Stadtroda, aged 76. 


\section{The Halle Chair}

The Halle Chair, probably the most important chair in the GDR, was initially given to Gertrud Schubart-Fikentscher. Born Gerturd Fikentscher in 1896 in Zwickau (Saxony), she grew up in a wealthy family that had for generations been industrialists and artists; her grandfather was founder of a chemical factory in Zwickau (Lauterbach, 2013). In 1916 she became a 'social engineer' (Fürsorgerin) and worked for a long time in Berlin. Confronted with the legal problems of juvenile delinquents, she attended Berlin University to improve her legal knowledge. In 1928 she married papyrologist Werner Schubart (1873-1960; Fikentscher, 2014). After passing the Prussian legal 'state examination,' she studied under Berlin legal historian Ernst Heymann and became one of the first female researchers in legal history. She wrote her thesis on German marriage law in the town Brünn in Moravia, continued research during National Socialism collaborating with Monumenta Germaniae Historica, and also taught at Leipzig University. In 1945 she became a member of the Social Democratic Party of Germany (Sozialdemokratische Partei Deutschlands, SPD) in Halle, the SPD being taken over by the SED in 1946. In 1948 she became the first German female legal professor, holding the chair of legal history at Halle. She continued in medieval German 'city law' (Stadtrechte; Schubart-Fikentscher, 1950) but mostly specialised in the history of natural law at Halle (Schubart-Fikentscher, 1960, and SchubartFikentscher, 1967) and she also served as the dean of the Halle Faculty of Law. In 1951 she left the SED without consequences and retired from the University in 1957. In 1959 Schubart-Fikentscher became a member of the Saxon Academy of Science in Leipzig. She still maintained ties to West Germany as a member of Monumenta Germaniae Historica in Munich and since 1971 as an author of many entries for Handwörterbuch zur Deutschen Rechtsgechichte. ${ }^{6}$ By the time of her death, she was one of the last survivors of the German pre-war academia. When she was born in 1896, Queen Victoria had still four years to live; when she died in 1985, Gorbachev was already the chairman of the Soviet Union Communist Party.

\section{And now for something completely different: The Babelsberg Conference 1958}

The Babelsberg Conference on April 2-3, 1958, represented a real fracture in East German legal science. Opened by Walter Ulbricht with a keynote speech written by Karl Polak, it marked a great rift with what remained of traditional jurisprudence (Eckert, 1993). 'Babelsberg' ended the illusion of at least a semiautonomous legal science in the GDR. Attempts to construct a discipline of 'Marxist' legal history ceased to exist after the Babelsberg Conference, and subsequent efforts to re-establish legal history were small. The festschrift for Erwin Jacobi also in 1957 was a case in point as it contained little reference to legal history (but see Brehme, 1957). ${ }^{7}$ By this time, traditional legal historians were a real minority, and everyone knew that legal history would never regain a major role in the GDR universities even in a Marxist sense. 
During the GDR years, legal history had no confirmed place in the regular legal studies. It was a 'marginalised science,' a discipline of scientific bystanders, isolated but international. It would have been easy to abolish legal history, but there was an official desire for a kind of reservation for remaining scientists, rated strange but harmless. In this reservation, personal continuity was high. Gerturd Schubart-Fikentscher was followed in 1957 by her first student Rolf Lieberwirth (1920-2019), ${ }^{8}$ who held the chair until 1986. The Lutheran Lieberwirth was, like Buchda, a member of the LDPD, and was called by Karl Kroeschell 'the last stronghold of civic legal history in the GDR,' and this hit the target exactly. (Stolleis, 2009, p. 94; Lieberwirth, 2005; Cordes, 2007). Lieberwirth focused on Sachsenspiegel-research and had strong collaboration with the Saxon Academy of Science. A related area of research with ties to East European legal history was 'Madgeburg Town Law' (Magdeburger Recht), which concerned areas in the socialist 'brother countries' (Bruderländer) Poland and the Soviet Union. Both areas of research also had special roots before 1949 (Lieberwirth, 1982; Lieberwirth, 1986a; Lück, 1999).

In Halle, local and specific field of research was natural law, and especially Christian Thomasius (Lieberwirth, 1955). This continued an old Halle tradition of research, begun by Max Fleischmann in 1928. Lieberwirth, who published a lot in 'non-socialist countries abroad' (Nichtsozialistisches Ausland'), retired in 1986 and was gradually replaced by his former student Heiner Lück (born 1954). ${ }^{10}$ In Jena, the long-time vacant chair was given in 1988 to Gerhard Lingelbach (born 1948), originally a student of Gerhard Haney. ${ }^{11}$ Lück and Lingelbach formed together with Lieberwirth scholar Bernd Schildt (born 1948) ${ }^{12}$ the last generation of the GDR legal history outside Berlin. However, the few happy scholars were more international than many GDR scientists and seemed more a part of the Western scientific community. Also, the Savigny-Zeitschrift, the leading German-speaking periodical for legal history, was published in the GDR town of Weimar.

On the other hand, East German legal historians were methodologically more conservative than their Western colleagues. The link with a worldwide community of researchers was gone with the extinction of Roman law, which in GDR only played a marginalised role in classical history (Härtel and Pólay, 1987). GDR legal history was very national, and the focus on German legal history was becoming old-fashioned in Western Germany. Academic life after 'Babelsberg' was largely quiet. The 'third university reform' (3. Studienreform) of 1967 closed down university institutes and also 'Academies for State and Law' that had played a large role in the reforms of the higher education in the early years of the GDR. At the level of university administration, however, significant efforts for saving the institutes were made-the institutes were simply changed into research 'areas' (Bereiche). There was no '1968' in the GDR, no 'New Universities,' no increased number of students, no 'university for the masses' (Massenuniversität), and no methodological controversies.

Legal historians remained careful, and even informal get-togethers between the minorities of legal historians and the very few students opposing the state were not remarkable at all. Legal historians in the socialist provinces lived in an academic 
bubble of Sachsenspiegel, town law and Enlightenment. This formed a restricted area of research between 'refuge and political justification' (Lück, 1998), very regionally based, and fitting for a Marxist 'historic heritage.' The objects of legal historical research included the famous law book Sachsenspiegel (i.e., literally 'Saxon Mirror'), early courts of appeal like the 'jury stool' (Schoppenstubl) in Thuringia and Saxony or the Wismar 'supreme court' (Obertribunal) (Wernicke, 1984) ${ }^{13}$ of the Baltic area. Natural law and the Enlightenment were the main focuses of research at Halle University. A remarkable 'long-term seller' was a small book on 'Latin in Law' written by Rolf Lieberwirth in 1986 (Lieberwirth, 1986c; second edition 1988).

Topics concerning modern phenomena, for example, the history of labour law (see Zierholz, 1985) or welfare legislation, never played a big role. Hence, Günther Baranowski in Berlin carried out research on Pufendorf (Baranowski, 1982) and Lieselotte Jelowik in Halle on the political struggle against criminal punishment for abortion ('\$2 218 StGB') in Weimar Republic (Jelowik, 1984). A legal history on the class struggle remained outside the possibilities of the minority. This was reserved for reliable Marxists like Polak and his successors (Schöneburg, 1975).

\section{Marxist Island: Berlin}

The West German trials of Uwe Wesel and others for 'legal historical materialism' (Materialistische Rechtsgeschichte) (Wesel, 1974), a Marxist approach, had no effect on the legal historiography written in the GDR. Legal historians accepted their role of not interfering with the official Marxist interpretation of law. Only Berlin played a special role with a more political legal history promoted by Horst Schröder (born 1930) ${ }^{14}$ and Marxist bystanders like Hermann Klenner (born 1926). Werner Sellnow (born $1913)^{15}$ approached legal history from a very Marxist point of view (Sellnow, 1968) but also in the secrecy of conferences abroad published on non-socialist lawyers like Hugo Preuss (Sellnow, 1972). A similar legal historian with a focus on the 19th and 20th centuries was Horst Kuntschke. ${ }^{16}$ Schröder first started as a lecturer in 1968 and obtained a chair in 1971 (Stolleis, 2009, p. 84). But these scholars, mostly members of the SED, acted mainly as legal philosophers (see Schröder, 1971). They formed a Marxist Wing of GDR legal history in the capital, close to the power and endangered (Lieberwirth, 1988, p. 199). Research on Prussian civil code 'General Land Law' (Allgemeines Landrecht) (Heuer, 1960) and Friedrich Carl von Savigny (Schröder, 1984) took place mostly in Berlin with its special circumstances and special challenges.

\section{Publishing and academia}

Important parts of legal history like Roman law, canon law or constitutional history did not exist at GDR universities. Some parts of research only took place at the 'Academies of Science.' However, some research groups in the GDR were internationally recognised. Such groups worked at the Academies of Science in Berlin and in Leipzig. The former concentrated on Byzantine Law (Winkelmann, 2002), the latter on Sachsenspiegel (Jelowik, 1998) and Magdeburg Law (Lieberwirth, 1986a). Ties to legal historians of Western Germany, Austria, 


\section{Martin Otto}

Switzerland and Scandinavia remained relatively strong during the whole GDR, and Savigny-Zeitschrift, the most important German-speaking journal of legal history, was also published in the GDR (Ogris, 2008).

\section{Legal history trickling down}

A part of the short-lived GDR legal history dealt with a small but secure cultural position. Some results of research 'trickled down' (Liebrecht 2018, p. 299) from academia. A lavish book called Unser Deutschland, introduced in 1957 as an official present for the socialist coming-of-age ritual called 'youth consecration' (Jugendweibe), interpreted German history as more national than socialist, noting the merits of famous Germans like Luther, Goethe (see SchubartFikentscher, 1977), Schiller (see Lingelbach, 1984), Lessing and related heroes. German Enlightenment was also represented by the lawyer Christian Thomasius (Zentralausschuss für Jugendweibe, 1957, p. 35):

Christian Thomasius (1655-1728) was a professor, solicitor and philosopher in Halle, who successfully stood up for the use of the German language in teaching instead of Latin at the university. ${ }^{17}$

Thomasius was mentioned more as an impassioned advocate of the German language than as a lawyer (though in this tradition, see Lieberwirth, 1987). This was another version of socialist 'Popular Front' (Volksfront), but Thomasius had to share his humble place in the book with the Communists Ernst Thälmann and Wilhelm Pieck. Mentioning Thomasius meant offering an intellectual homeland to non-socialist citizens. Unser Deutschland was inspired by the more intellectual Marxist scientist Paul Wandel (Neubert, 1997, p. 119) and it was replaced again in 1958 by its 1954 precursor, the more communistic and atheistic 'Space-Earth-Man' (Weltall-ErdeMensch), and so the references to the enlightened lawyer Thomasius disappeared.

Scholarly without a doubt was the 1973 publication of 'Atlas of History' (Atlas zur Geschichte), which continued a special German tradition (Wolf, 1977) begun in 1886 by Gustav Droysen, that was also observed in West Germany even in the conservative newspaper Frankfurter Allgemeine Zeitung in 1974. The versatile 'atlas' offered legal history a small place on the map, seeing the spread of 'Magdeburg Law' in Eastern Europe. This spread was interpreted from a Marxist perspective as a part of the history of feudalism (Zentralinstitut für Geschichte, 1973, p. 32): 'The Feudal German eastward expansion' (Die feudale deutsche Ostexpansion (10.-14. Jh.)

The Luther Jubilee in 1983 meant an opportunity to present the GDR as a culturally and religiously free state. This also gave room for 'Legal History's Contribution' written by Gerhard Lingelbach (Lingelbach, 1983) and Hermann Klenner (Klenner, 1983). In practice this was more a surviving strategy for an endangered species than the real desire of a very secure GDR at the climax of its international recognition. The jubilee of the revolutionary theologian Thomas Müntzer in 1989 had even less of an impact for legal history (but see Lück, 1989). 


\section{The last bid}

Continuing the mode of the Luther Jubilee, the newly introduced history calendar in the official periodical Staat und Recht (Mohnhaupt, 1984) represented the last concerted effort to maintain GDR legal history. In the last years of the GDR, the jubilees were initiated by Gerhard Lingelbach. In 1989 he remembered the birthdays of Montesquieu, Max Weber and even the 70th anniversary of the Weimar Constitution, the 'most progressive German constitution in power at that time' (Lingelbach, 1989, pp. 69, 71, 74). When Lingelbach wrote his history calendar for 1990, German reunification in 1990 was not yet predicted. As worthwhile Jubilees Lingelbach picks the 100th anniversary of the abolishment of Bismarck's anti-socialist law (Sozialistengesetz), the 150th anniversary of August Bebel, and the 50th anniversary of the death of Hermann Kantorowicz (Lingelbach, 1990, p. 82-83). The 175th birthday of Bismarck, praised for his 'modest realism' (Realitütssinn mit Augenmaß) in foreign politics, was mentioned equal to the 30th anniversary of the death of Communist GDR President and 'popular statesman' (volkstümlicher Staatsmann) Wilhelm Pieck (Lingelbach, 1990, pp. 85, 91). Lingelbach ended his calendar with the putative 800th birthday of Eike von Repgow (Lingelbach, 1990, p. 95). So GDR legal history ended with an outmoded date, as seen from a contemporary Western point of view, but it also showed impressive Janus-faced discipline.

\section{Conclusion}

In its first years the GDR had to face an enormous brain drain to the West, and jurisprudence was heavily affected as well. Despite all 'antifascist' and revolutionary rhetoric, it was not in the interests of the GDR and its leading party SED to burn all the bridges behind. The SED could not dismiss the importance of universities in its socialist project, and as a result the need for academics was real. As far as the legal studies in the German tradition were concerned, legal historians and the GDR government shared a common goal of maintaining legal historical studies in the remaining universities with legal faculties. Legal historians like Gerhard Buchda and Gertrud Schubart-Fikentscher were fully integrated members of the early GDR academia-with strong but quiet roots in the years before 1945. Their 'bourgeois' approach to legal history was not a problem as long as the research themes were specific and dealt with distant times. The presence of non-socialist scientists, and not only in legal history, was mostly welcome. It seemed to prove that recognised scientists, too, could find a place in the GDR, but in reality, that place was narrow and endangered.

Already during the first years of the GDR, the teaching of and research on legal history was heavily diminished in comparison to the pre-war universities. The 'Babelsberg conference' was a turning point for legal science in the GDR. It marked a change to a more applicative and political legal science, but legal history as discipline was hardly affected. The discipline continued to play an insignificant role inside and outside academia, but its international recognition was 


\section{Martin Otto}

indispensable. Thus, the discipline was allowed to encapsulate to its own research dimension. This was the reason for the relatively conservative GDR approach to legal history. Legal history was parochial, knotted with the 'province,' or with the neighbouring universities of Halle and Jena. The areas of research emphasised 'regional' items like the Sachsenspiegel and Halle Enlightenment. From the point of view of the SED, this was harmless.

In the academic sphere of Berlin, legal history played a special role in the vicinity of legal philosophy. There historically oriented legal scholars-like Horst Schröder-were Marxists and mostly members of the SED. They had to face a stronger supervision by the SED and were more at odds with the official ideas of proper legal science. Conflicts were numerous. Legal history did not, however, lose its jurisprudential prestige and significance to legal philosophy. In fact, legal philosophers were even more endangered, at risk of unwanted party attention and consequent sanctions - of which the fate of Hermann Klenner is a good example. Yet, many legal historians, like Gerhard Lingelbach, had roots in legal philosophy.

Classical legal history was written outside the capital. The GDR legal historians, except for a small number of Marxists, formed a kind of scientific cloister throughout these years-a refuge that was sometimes called upon by their Marxist colleagues when 'historical background' was required. German reunification ended the GDR, but some scholars got an opportunity to continue and succeed in the new unified Germany and abroad. The end of the GDR was followed by the end of the scientific sanctuary of distant and specific research topics for the few GDR legal historians. The challenge to explain why as modern lawyers we need to know about Sachsenspiegel is still a valid issue in all parts of Germany.

\section{Notes}

1 Erwin Jacobi in a letter to Eugen Rosenstock-Huessy, 'Leipzig p. 3, November 8, 1946: In Berlin however prevails a conservatism that would preferably fall back on the course catalog of 1912.' (Leipzig S 3, am 8 . November 1946. In Berlin allerdings herrscht ein Konservatismus, der am liebsten auf die Vorlesungsverzeichnisse von 1912 zurückgreifen möchte); quoted in Otto (2008), p. 276-277.

2 'Und so wie damals gehörte nun zum Volksfront-Konzept in der DDR im Bereich der Kultur natürlich die Allianz mit den bürgerlichen, traditionellen, konservativen Universitätsleuten. Sie durften nicht kritisiert werden.'

3 'Bei der Rechtsgeschichte handelte es sich um einen in der DDR vom Beginn bis zum Ende ihrer Existenz politisch diffamierten und theoretisch diskreditierten Wissenschaftszweig.'

4 William Shakespeare, Henry V., IV, 3: 'We few, we happy few, we band of brothers $[\ldots]$.'

5 Buchda's articles include 'Altmärkische Glosse zum Sachsenspiegel,' 'Aktenversendung,' 'Anklage,' 'Anwalt,' 'Appellation,' 'Appellationsprivilegien,' 'Artikelprozeß,' 'Berufung,' 'Beschlagnahme,' 'Beweisinterlokut,' 'Büttel,' 'Cautelarjurisprudenz,' 'Contumacia,' 'Delegation,' 'Einlassung,' 'Fallrecht,' 'Freischöffe,' 'Freistuhl,' 'Fronbote,' 'Fronung,' 'Gebundene Tage,' 'Gelehrte Richter,' 'Gelöbnis,' 'Gemeines Sachsenrecht,' 'Gerichtsgefälle,' 'Gerichtsverfahren,' 
'Gerichtsverfassung,' 'Gerüfte,' 'Gesamthand, gesamte Hand,' 'Görlitzer Rechtsbuch,' 'Heimbürge,' 'Hermann von Oesfeld,' 'Jus evocandi,' 'Klage,' 'Kursächsische Konstitutionen,' 'Kummer,' 'Läuterung,' 'Landfriedensgericht,' 'Landgemeinde,' 'Landrechtsbücher,' 'Landrechtsglosse,' 'Laten,' 'Leipzig' and 'Magdeburger Recht.'

6 Schubart-Fikentscher's articles include 'Johannes Althusius,' 'Karl von Amira,' 'Matthias Berlichius,' 'Georg Beseler,' 'Just Henning Böhmer,' 'Sebastian Brant,' 'Heinrich Brunner,' 'Benedict Carpzov,' 'Emil Goldmann' and 'Johannes Friedrich Harpprecht' (all 1971). For Neue Deutsche Biographie she wrote articles on Wilhelm von Brünneck, Dietrich II. bishop of Naumburg, Max Fleischmann, Christian Gottlieb Haubold, Ernst Heymann and Carl Gustav Homeyer (1955-1972).

7 For contemporary Marxist criticism see Otto (2008), pp. 366-381.

8 PhD thesis: Die gesetzlichen Pfandrechte zur Zeit der Aufklärung unter besonderer Berücksichtigung der Halle-Wittenberger Juristen Augustin Leyser und Samuel Stryk, Halle 1952.

9 For Handwörterbuch zur Deutschen Rechtsgeschichte Lieberwirth wrote during the GDR period (all 1971) the articles 'Amtsvergehen (Amtsverbrechen)' 'Angstmann,' 'Armesünder,' 'Auslieferung von Missetätern,' 'Ausstäupen,' 'Beleidigung,' 'Bigamie (Doppelehe),' 'Carolina,' 'Crimen laesae maiestatis (Majestätsverbrechen),' 'Diebstahl,' 'Ehebruch,' 'Entführung (crimen raptus),' 'Entmannung,' 'Ertränken,' 'Feldfrevel,' 'Folter,' 'Freiheitsstrafe,' 'Frevel,' 'Friedebann,' 'Gefangene, Gefängnis,' 'Glücksspiel,' 'Gotteslästerung,' 'Gundling, Nicolaus Hieronymus,' 'Haftstrafe,' 'Halsgerichtsordnungen' and 'Halslösung'; for Lexikon des Mittelalters the article 'Eike von Repgow' (1985), for Neue Deutsche Biographie (1961-1971) articles on August Finger, Ernst von Globig, Nicolaus Gundling, Gottlieb Heineccius and Karl Ferdinand Hommel, for Kindlers Literaturlexikon (1971) an article on Thomasius, De Crimine Magiae.

$10 \mathrm{PhD}$ thesis: Die Spruchtätigkeit der Wittenberger Juristenfakultät, Halle 1982; 'Habilitation': Die kursächsische Gerichtsverfassung von 1423 bis zur Mitte des 16. Jahrhunderts unter besonderer Berücksichtigung der landesherrlichen Gerichtsorganisation, Halle 1988.

11 PhD thesis: Das Verhältnis der deutschen Rechtswissenschaft, insbesondere der Juristenfakultät der Universität Jena, zur Französischen Revolution zwischen 1789 und 1820, Jena 1978; 'Habilitation': Änderungen der Beschuldigtenstellung bei der Überwindung des feudalen Inquisitionsprozesses im Spiegel der deutschen Rechtswissenschaft, Jena 1985.

12 PhD thesis: Die Spruchtätigkeit der Halleschen Juristenfakultät nach dem Wiener Kongress, Halle 1980; 'Habilitation': Verfassung und Wirtschaftsrecht der spätfeudalen Landgemeinde im Spiegel thüringischer Dorfordnungen, Halle 1988.

13 The courts of 'Hanse' were part of common history and so increased after 1989.

$14 \mathrm{PhD}$ thesis: Die antidemokratische und antinationale Politik der rechten SPDFührung in den Jahren 1945-1952, Berlin 1961. 'Habilitation' (1976): Schröder, 1984.

15 PhD thesis: Gesellschaft-Staat-Recht. Zur Kritik der bürgerlichen Ideologien über die Entstehung von Gesellschaft, Staat und Recht von der bürgerlichen Aufklärung bis zum deutschen Positivismus des 19. Jahrhunderts, Berlin 1963; 'Habilitation': Zum Problem der Rechtsgeschichte im Werk von Marx und Engels, Berlin 1968.

$16 \mathrm{PhD}$ thesis: Die geschichtliche Stellung des Reichsgerichts im Deutschen Kaiserreich von 1871 und seine Rechtsprechung zu den demokratischen Freiheiten gegenüber der Arbeiterklasse, Berlin 1964. 
17 Christian Thomasius (1655-1728) war Professor, Jurist und Philosoph in Halle und trat mit Erfolg für den Gebrauch der deutschen Sprache an Stelle der lateinischen im Lehrbetrieb der Universität ein.'

\section{References}

Baranowski, G. (1982) 'Samuel Pufendorf-ein Vorkämpfer der bürgerlichen Staatsund Rechtslehre. Zum 350. Geburtstag', Staat und Recht, 31, 58-64.

Brehme, G. (1957) 'Die Verstaatlichung der Kohlebergbaurechte in Sachsen und die Novemberrevolution von 1918', in Bönninger, K., Such, H. and Arzinger, R. (eds), Festschrift Erwin Jacobi, Berlin: Deutscher Zentralverlag, 164-196.

Brun, G. (1991) Leben und Werk des Rechtshistorikers Heinrich Mitteis unter besonderer Berücksichtigung seines Verhältnisses zum Nationalsozialismus, Frankfurt am Main: Peter Lang.

Buchda, G. (1938) 'Wirtschaftsrecht in jüngeren thüringischen Landesordnungen', in Freisler, R., Löning, G. A. and Nipperdey, H. C. (eds), Festschrift Justus Wilhelm Hedemann zum sechzigsten Geburtstag am 24. April 1938, Jena: Frommann, 34-50.

Buchda, G. (1954-1962) Die Schöffenspruchsammlung der Stadt Pößneck, 4 vol., Weimar: Böhlau.

Buchda, G. (1976) 'Testament und Nachlaß des Naturforschers Alfred Edmund Brehm', in Becker, H.-J. (ed), Rechtsgeschichte als Kulturgeschichte. Festschrift für Adalbert Erler zum 70, Geburtstag, Aalen: Scientia, 591-610.

Cordes, A. (2007) Interview mit Prof. Dr. Rolf Lieberwirth am 12. September 2007 in Halle (21. December 2007) forum historiae iuris, https://forhistiur.de/200712-cordes/ (accessed 20.12.2019).

Eckert, J. (ed) (1993) Die Babelsberger Konferenz vom 2./3. April 1958, BadenBaden: Nomos.

Fikentscher, R. (2014) Liebe, Arbeit, Einsamkeit. Wilhelm Schubart, Papyrologe. Gertrud Schubart-Fikentscher, Rechtshistorikerin. Ein Gelehrtenpaar in zwei Diktaturen, Halle (Saale): Mitteldeutscher Verlag.

Härtel, G. and Pólay, E. (1987) Römisches Recht und römische Rechtsgeschichte, Eine Einführung, Weimar: Böhlau.

Haferkamp, H.-P. (2010) 'Wege der Historiographie zur Privatrechtsgeschichte der Neuzeit', Zeitschrift für Neuere Rechtsgeschichte, 32, 61-81.

Handschuck, M. (2003) Auf dem Weg zur sozialistischen Hochschule. Die Universität Rostock in den Jahren 1945 bis 1955, Bremen: Edition Temmen.

Heuer, U.-J. (1960) Allgemeines Landrecht und Klassenkampf. Die Auseinandersetzungen um die Prinzipien des allgemeinen Landrechts Ende des 18. Jabrhunderts als Ausdruck der Krise des Feudalsystems in Preußen, Berlin: Deutscher Zentralverlag.

Jelowik, L. (1984) 'Der Kampf der KPD gegen \$ 218', Staat und Recht, 33, 671-675.

Jelowik, L. (1998) 'Der Sachsenspiegel als Gegenstand des akademischen Unterrichts an der halleschen Juristenfakultät im 19. und 20. Jahrhundert', in Lieberwirth, R. (ed), Rechtsgeschichte in Halle, Köln, Berlin, Bonn and München: Carl Heymanns, 69-80.

Klenner, H. (1983) 'Recht wider Recht bei Martin Luther', Staat und Recht, 32, $867-873$.

Lauterbach, I. R. (2013) Friedrich Christian Fikentscher (1799-1864), ein früher Chemiefabrikant. Unter Berücksichtigung seiner Briefe aus den Jabren 1823, 1824 und 1830, Stuttgart: Wissenschaftliche Verlagsgesellschaft. 
Lenski, K. (2017) Geheime Kommunikationsräume? Die Staatssicherheit an der Friedrich-Schiller-Universität Jena, Frankfurt am Main and New York: Campus.

Lieberwirth, R. (1955) Christian Thomasius. Sein wissenschaftliches Lebenswerk. Eine Bibliographie, Weimar: Böhlau.

Lieberwirth, R. (1982) Eike von Repchow und der Sachsenspiegel, Berlin: Akademie.

Lieberwirth, R. (1986a) Das sächsisch-magdeburgische Recht als Quelle osteuropäischer Rechtsordnungen, Berlin: Akademie.

Lieberwirth, R. (1986b) 'Die Rechtshistoriker an der Leipziger Juristenfakultät in der ersten Hälfte des 20. Jahrhunderts', in Kroeschell, K. (ed) Festschrift für Hans Thieme zu seinem 80. Geburtstag, Sigmaringen: Thorbecke, 391-402.

Lieberwirth, R. (1986c) Latein im Recht, Berlin: Staatsverlag der DDR (simultaneously Heidelberg: C. F. Müller).

Lieberwirth, R. (1987) 'Christian Thomasius und die deutsche Sprache im Universitätsbetrieb', Staat und Recht, 36, 768-770.

Lieberwirth, R. (1988) 'Die Rechtsgeschichte in der DDR', Zeitschrift für Neuere Rechtsgeschichte, 10, 194-205.

Lieberwirth, R. (2000) 'Der erste weibliche Professor ordinarius an einer Juristenfakultät im deutschsprachigen Raum', Rechtshistorisches Journal, 19, 619-623.

Lieberwirth, R. (2005) 'Meine erste Begegnung mit dem Rechtswissenschaftlichen Seminar bei der Hallischen Juristenfakultät', in Lück, H. (ed) 150 Jahre Juristisches Seminar der Martin-Luther-Universität Halle-Wittenberg, Halle (Saale): Stekovics, 59-63.

Lieberwirth, R. (2010) Geschichte der Juristischen Fakultät der Universität HalleWittenberg nach 1945. Fakten und Erinnerungen, Halle (Saale): UniversitätsVerlag Halle-Wittenberg.

Liebrecht, J. (2018) Die junge Rechtsgeschichte. Kategorienwechsel in der rechtshistorischen Germanistik der Zwischenkriegszeit, Tübingen: Mohr Siebeck.

Lingelbach, G. (1983) 'Yhe weniger Gesetz, yhe besser Recht'. Zu den Auffassungen von Martin Luther zum spätfeudalen Recht', Staat und Recht, 32, 851-859.

Lingelbach, G. (1984) 'Friedrich Schiller und sein Staatsverständnis. Zum 225. Geburtstag des Dichters am 10. November 1984', Staat und Recht, 33, 842-847.

Lingelbach, G. (1989) 'Kalendarium zur Geschichte von Staat und Recht und seiner Wissenschaft für das Jahr 1989', Staat und Recht, 38, 69-79.

Lingelbach, G. (1990) 'Kalendarium zur Geschichte von Staat und Recht und seiner Wissenschaft und seiner Wissenschaft für das Jahr 1990', Staat und Recht, 39, 82-95.

Lingelbach, G. (2008) 'Gerhard Buchda (1901-1977)', in Cordes, A., Haferkamp, H.-P., Lück, H. and Werkmüller, D. (eds) Handwörterbuch zur Deutschen Rechtsgeschichte, vol. 1, Berlin: Erich Schmidt, 698-699.

Lück, H. (1989) 'Beobachtungen zu Zehnt, Zins und anderen Abgaben in den Urkunden des Klosters Kaltenborn', in Gesellschaft für Heimatgeschichte im Kulturbund der DDR, Bezirksfachausschuss Numismatik (ed) Thomas Müntzer und die frübbürgerliche Revolution. Thomas-Müntzer-Ehrung der DDR 1989. Münzausstellung, 30. April bis 11. Juni 1989 in Bad Frankenhausen, Halle (Saale): Gesellschaft für Heimatgeschichte, 24-34.

Lück, H. (1998) 'Zwischen Refugium und Systemrechtfertigung. Rechtsgeschichte in der DDR', in Lück, H. (ed) Recht und Rechtswissenschaft im mitteldeutschen Raum. Symposium für Rolf Lieberwirth zu seinem 75. Geburtstag, Köln, Wien and Weimar: Böhlau, 165-176. 


\section{Martin Otto}

Lück, H. (1999) “'Der Deutsche kommt also im Osten in kein Neuland...' Das Institut zur Erforschung des Magdeburger Stadtrechts (1940-1945)', in Lück, H. and Freitag, W. (eds) Historische Forschung in Sachsen-Anhalt. Ein Kolloquium anläßlich des 65. Geburtstages von Walter Zöllner, Stuttgart and Leipzig: Hirzel, 125-145.

Mechow, M. (1970) Nambafte CCer. Kurzbiographien verstorbener Landsmannschafter und Turnerschafter, Stuttgart-Möhringen: Verband Alter Herren des Coburger Covents, 277-278.

Mitteis, H. (1947) 'Rechtsgeschichte und Gegenwart', Neue Justiz, 1, 27-29.

Mohnhaupt, H. (1984) 'Beobachtungen zur Rechtsgeschichte der DDR im Spiegel der Zeitschrift 'Staat und Recht', Ius Commune, XII, 253-285.

Müller, H. (1992) Krieg obne Schlacht. Leben in zwei Diktaturen, Köln: Kiepenheuer \& Witsch.

Neubert, E. (1997) Geschichte der Opposition in der DDR. 1949-1989, Berlin: Christoph Links.

Ogorek, R. (1994) 'Rechtsgeschichte in der Bundesrepublik Deutschland 1945-1990', in Simon, D. (ed) Rechtswissenschaft in der Berliner Republik. Studien zur Wissenschaftsgeschichte der Jurisprudenz, Frankfurt am Main: Suhrkamp, 12-99.

Ogris, W. (2008) 'Zum Erscheinen von Band 125 der Zeitschrift der SavignyStiftung für Rechtsgeschichte', Zeitschrift der Savigny-Stiftung für Rechtsgeschichte (Germanistische Abteilung), 125, XXXI-XLVIII.

Otto, M. (2004) 'Werner Weber-ein Opfer der politischen Säuberung nach 1945', Sächsische Verwaltungsblätter, 12, 201-205.

Otto, M. (2008) Von der Eigenkirche zum Volkseigegen Betrieb: Erwin Jacobi (1884-1965). Arbeits-, Staats- und Kirchenrecht zwischen Kaiserreich und DDR, Tübingen: Mohr Siebeck.

Otto, M. (2009) 'Öffentliches Recht und Arbeitsrecht: Erwin Jacobi (1884-1965)', in Lege, J. (ed) Greifswald-Spiegel der deutschen Rechtswissenschaft 1815 bis 1945, Tübingen: Mohr Siebeck, 303-321.

Polak, K. (1947) 'Wesen und Wert der Rechtsgeschichte', Neue Justiz 1947, 1, 54-58.

Rückert, J. (1995) 'Abbau und Aufbau der Rechtswissenschaft nach 1945', Neue Juristische Wochenschrift, 48, 1251-1259.

Schöneburg, K.-H. (1975) 'Wissenschaft von der Geschichte der Staats- und Rechtstheorie: Notwendigkeit, Konzeption, Aufgabe. Zum 70. Geburtstag von Karl Polak', Staat und Recht, 24, 1457-1466.

Schröder, H. (1984) Friedrich Karl von Savigny. Geschichte und Rechtsdenken beim Übergang vom Feudalismus zum Kapitalismus in Deutschland, Frankfurt am Main: Peter Lang.

Schröder, H. (1971) Eduard Gans, Philosophische Schriften. Herausgegeben und eingeleitet von Horst Schröder, Berlin: Akademie.

Schröder, H. (2001) 'Polak versus Mitteis', in Schröder, H. and Simon, D. (eds) Rechtsgeschichtswissenschaft in Deutschland 1945-1952, Frankfurt am Main: Vittorio Klostermann, 5-18.

Schubart-Fikentscher, G. (1950) Quellen zur deutschen Privatrechtsgeschichte vor der Rezeption, Weimar: Böhlau.

Schubart-Fikentscher, G. (1960) Hallesche Spruchpraxis. Consiliensammlung Hallescher Gelehrter aus dem Anfang des 18. Jahrhunderts, Weimar: Böhlau. 
Schubart-Fikentscher, G. (1967) Die Unehelichen-Frage in der Frübzeit der Aufklärung, Berlin: Akademie.

Schubart-Fikentscher, G. (1977) Goethes amtliche Schriften. Eine rechtsgeschichtliche Untersuchung, Berlin: Akademie.

Sellnow,Werner (1968). Zum Problem der Rechtsgeschichte im Werk von Marx und Engels, Berlin.

Sellnow, W. (1972) 'Hugo Preuss, ein Verwaltungsrechtler im Kampf mit dem preußischen Verwaltungsrecht', in Csizmadia, A. (ed) Entwicklungsfragen der Verwaltung in Mitteleuropa. Aus Materialien der Internationalen Konferenz über Verwaltungsgeschichte in Pécs-Siklós 18.-20. Mai 1972, Pécs: Pécsi Tudományegyetem Állam- és Jogtudmányi Kara, 229-252.

Soldwisch, I. (2007) '...etwas für das ganze Volk zu leisten und nicht nur den Zielen einer Partei dienen'. Geschichte der Liberal-Demokratischen Partei in Mecklenburg 1946-1952, Berlin and Münster (Westf.): Lit.

Steiger, G. (1980) Ich würde doch nach Jena gehen. Geschichte und Geschichten, Bilder, Denkmale und Dokumente aus 4 Jahrhunderten Universität Jena, Weimar: Böhlau.

Stolleis, M. (2009) Sozialistische Gesetzlichkeit. Staats- und Verwaltungsrechtswissenschaft in der DDR, München: C. H. Beck.

Tilitzki, C. (2002) Die deutsche Universitätsphilosophie in der Weimarer Republik und im Dritten Reich, vol. 1, Berlin: Akademie.

Wahl, V. (1999) 'Erweiterung und Neuaufbau 1945', in Post, B. and Wahl, V. (eds) Thüringen-Handbuch. Territorium, Verfassung, Parlament, Regierung und Verwaltung in Thüringen 1920 bis 1995, Weimar: Böhlau, 41-51.

Waibel, H. (2011) Diener vieler Herren. Ehemalige NS-Funktionäre in der SBZ/ $D D R$, Frankfurt am Main, Berlin, New York and Paris: Peter Lang.

Wernicke, H. (1984) Studien zum Verbältnis der Städtehanse zum norddeutschen Fürstentum und zum Reich, Thesis (B) Greifswald University.

Wesel, U. (1974) 'Zur Methode der Rechtsgeschichte', Kritische Justiz, 7:4, $337-368$.

Will, R. (2010) 'Die Juristische Fakultät in der DDR', in Grundmann, S. (ed) Festschrift 200 Jahre Juristische Fakultät der Humboldt-Universität zu Berlin. Geschichte, Gegenwart und Zukunft, Berlin und New York: Walter de Gruyter, 797-848.

Winkelmann, F. (2002) 'Als Kirchenhistoriker in der Berliner Akademie der Wissenschaften', in Meyer, D. (ed) Kirchengeschichte als Autobiographie. Ein Blick in die Werkstatt zeitgenössischer Kirchenhistoriker, vol. 2, Köln: Rheinland, 367-407.

Zentraler Ausschuss für Jugendweihe (1957) (ed.) Unser Deutschland. Ein Buch für alle, die es lieben, Berlin: Neues Leben.

Zentralinstitut für Geschichte der Akademie der Wissenschaften der DDR (ed) (1973) Atlas zur Geschichte, vol. 1: Von den Anfängen der menschlichen Gesellschaft bis zum Vorabend der Großen Sozialistischen Oktoberrevolution, Gotha and Leipzig: Hermann Haack.

Zierholz, H.-P. (1985) Arbeiterschaft und Recht in Brandenburg-Preußen. 1648-1800, Weimar: Böhlau. 